\title{
Rare Birds of North America
}

By Steve N. G. Howell, Ian Lewington, and Will Russell. 2013. Princeton University Press, 41 William Street, Princeton, NJ, USA, 08540-5237. 448 pages, 35.00 USD, Cloth.

The avid lister will need to wear a bib for this book as it contains all the species they will drool over. The authors include all the species seen in North America five times or less since the 1950s. These are the real rarities or "mega-ticks" that move the combat birders to drive for hours to add them to their lists.

Rarities come at us from three directions. Some sweep in on winds from Europe, others overrun their territory from the south and some blow over from eastern rim of Asia. Not surprisingly the east coast (Newfoundland to Maine), the states that border Mexico and Alaska's outer islands account for a high proportion of these strays. Record committees have to evaluate new sightings, taking in to account the bird's migratory tendencies, records of movements in other countries as well as the evidence provided by the observer. For example, if a European finch is found in Newfoundland, the committee will consider if the species has a history of wandering, is it being seen in Iceland or Greenland and is it a popular cage bird. The authors have taken all the accepted rarity records to 2011 plus a few later sightings. For this book the authors have stretched these limits and include some species that have questionable provenance, yet may be true records for a coverage of 262 species. For example, the authors discuss the records of the Common Shelduck, a bird usually dismissed as an escapee by the ABA, on the grounds that it is possible some may be true vagrants. They do not include species that breed annually even though they may be vagrants for most of the continent (Eastern Yellow Wagtail). The book has a North American focus so it does not include many rare Canadian birds (such as Thick-billed Kingbird) as these are frequently inhabitants of the southern States.

Before reading the species accounts the buyer needs to read the introduction, as it contains much thoughtprovoking information. There are discussions on migration and vagrancy, the influence of weather, mis-orientation and disorientation and dispersal. The authors introduce the concept of false vagrancy - birds that are rarely seen but are probably regularly occurring species (European Storm Petrel, Red-footed Booby). These birds are in areas that simply lack coverage. The introduction also covers topography moult and aging; complex topics that need to be considered for any vagrant.

I was surprised by the author's use of Light-mantled Sooty Albatross instead of the currently accepted Light-mantled Albatross (Phoebetria palpebrata). They also include the Eurasian Hen Harrier (Circus cyaneus) as a separate species to the Northern Harrier (Circus [cyaneus] husonicus), a split I have not seen accepted elsewhere. (Although I have always thought they were different species, based on their behaviour). There is an error in the index for Little Shearwater as the quoted page 98 is devoted to paintings of Thalassarche albatrosses.

The book is beautifully illustrated by Ian Lewington. The paintings are technically accurate, but also capture the specie's attitude effectively. For example, Lewington catches the funny, hunched posture of swallows, the perky look of a Hoopoe and the grace of the frigatebirds. Most birds are shown in different positions or plumages as appropriate. The artist frequently includes common, look-alike species (like Common and Spotted Sandpipers, Little and Snowy Egret). I have seen about half of the birds in this book, just not in North America. So I really enjoyed looking at illustrations as they evoked pleasant memories. This alone made the book worthwhile for me.

One of my most recent lifers was the Himalayan Bluetail or Orange-flanked Bush-robin. The vagrant listed in this book is the Red-flanked Bluetail once considered a subspecies Tarsiger c. cyanurus breeding in northern Asia with T. c. rufilatus breeding in the Himalayas. The Himalayan Bluetail is now considered by some as T. rufilatus, a distinct species. Given the aggressive attention to detail by records committees as carried into this book I was surprised not to see this possibility considered. The more northern Red-flanked Bluetail, if accepted as a split, is a long distance migrant rather than a short-distance altitudinal migrant so it is the more likely vagrant. The plates are lovely though and they did bring up my views of this pretty little bird along the roads around Darjeeling.

Clearly this is a must buy book for the passionate list keepers, particularly those who are strongly competitive. But there are good reasons for the rest of us owning this book. When examining the details for a rare species the authors need to consider the differences to common birds. For example, separating the European Storm Petrel from the more abundant Wilson's Storm-petrel. These careful comparisons teach me points of identification that I have overlooked for years. I await the return of our American Coots so I can check the under-tail coverts, something I have never done on the thousands of coots I have seen. I will look for the pale orange bill base on the Green-winged Teal (My photo of a male does not show this, but it may be the angle. I searched the net images and this is a very, very difficult to see field mark. Good luck if you find a vagrant Garganey). I will look for the black mark at the base of the wings of a Great Blue Heron. Maybe I will be able to see the plain primaries on an American Woodcock if I use a better flashlight. It is an education of field observation just to read this book. It is great value for the price and a highly recommended purchase for all birders.

ROY JOHN

2193 Emard Crescent, Beacon Hill North, Ottawa, ON, Canada, K1J $6 \mathrm{~K} 5$ 